\title{
Proximate and Quantitative Phytochemical Analysis of Detarium microcarpum (Sweet Detar) Fruit Pulp
}

\author{
Yusuf Umar $^{1 *} \quad$ Hauwa Hashim $^{2} \quad$ Zainab Uthman Muhammad ${ }^{1}$ \\ 1.Department of Science Laboratory Technology, Federal College of Agricultural Produce Technology Kano, \\ Nigeria \\ 2.Department of Biochemistry, Faculty of Science, Yobe State University, Damaturu, Nigeria
}

\begin{abstract}
The study was carried out to determine the proximate and quantitative phytochemical analysis of two species of Detarium microcarpum from Kano state, north-western Nigeria. Proximate composition of sample A shows a moisture content of $13.86 \pm 0.002$, Ash content $3.73 \pm 0.030$, lipid content $9.40 \pm 0.059$, crude protein $21.20 \pm 0.360$, crude fiber $4.52 \pm 0.038$ and carbohydrate $47.50 \pm 1.06$, while sample B shows a moisture content of $14.32 \pm 0.082$, Ash content $2.27 \pm 0.360$, lipid content $4.72 \pm 0.372$, crude protein $17.88 \pm 0.102$, crude fiber $4.46 \pm 0.062$ and carbohydrate 5.48 \pm 0.338 . Quantitative phytochemical screening of the fruit A shows $3.16 \%$ tannin, $10.73 \%$ saponin, $7.27 \%$ alkaloid and $8.56 \%$ flavonoid for sample while sample B contains $2.39 \%$ tannin, $11.2 \%$ saponin, $7.41 \%$ alkaloid and $7.63 \%$ flavonoid. Comparism between the samples shows specie A to be nutritionally rich compared specie B.
\end{abstract}

Keywords: Detarium microcarpum; Fruit; Proximate; Phytochemical and Pulp.

DOI: $10.7176 / \mathrm{JBAH} / 11-16-04$

Publication date:August $31^{\text {st }} 2021$

\subsection{Introduction}

Detarium microcarpum is an African tree belonging to the family Casalpiniaceae. The three height reaches up to $15 \mathrm{~cm}$ and it can reach $25 \mathrm{~mm}$ in most areas. The tree can be easily distinguished by its broken grey bark, with dark green, $8-12 \mathrm{~cm}$ leaves (Taita, 2003). The tree is widely distributed in dry savannah area of Africa and mostly in Northern Nigeria. The fruit is enable and rich in vitamin $\mathrm{C}$ and the leaves and seeds are also used in cooking the pulverized seeds cotyledons are used in some Africa Countries a compositional studies of the legumes revealed that it is a rich source of polysaccharide gum (Kouyaté and Lamien, 2012). In most developing countries food shortage is becoming evident as a result of population growth competition for fertilize land and poverty. The diet of many rural and urban dweller is deficient in protein and high in Carbohydrate (Vautier et al., 2007). The implication is high incidence of malnutrition and increased dietary disease, a situation in which children and lactating women are most vulnerable, while every measure is being taken by various level of government to boost food production by conventional of agriculture, a lot of interest is currently being focused on the possibilities of exploiting the most Number of less Familiar plant result source of the wild (Kouyate and Lamien, 2012).

Many of such wild plant have been identified but lack of data on their chemical composition has limited the prospect of their utilization known seeds (Vautier et al., 2007). Many report on Detarium microcarpum seeds indicate that they could be good sources of Nutrients for both man and livestock. It is widely distributed in semiarid sub-saharan African which include Benin, Burkina Faso, Cameroon, Central Africa, Republic, Ghana, Guinea, Bissau, Niger, Nigeria, Senegal and Togo (Abdalbasit et al., 2009).

The leaves and seeds are used for cooking the roots, stem bark and stems are also used to treat ailment like meningitis, tuberculosis, itches and diarrhea (Abdalbasit et al., 2009) The seed coat of the fruit has also been shown to possess antimicrobial activities due to presence on sleroidal, saponin and flavoniods (Barminas et al., 2012). Obun et al (2011) reported that when fruit pulp of Deterium microcarpum is included in the diet of rat, hematological parameters and body weight of rat changes, they concluded that prolonged consumption of the fruit by human affect hematological parameters and body weight. The seed flour is a traditional emulsifying, flavoring and thickening agent used to prepare cakes, bread, couscous, body food and local beer (Olugbuyiro et al., 2009).

\subsection{Materials and Methods}

\subsection{Sample Collection and Preparation}

The fruits of Detarium Microcarpum was collected from Rimi Market Nassarawa Local government Kano State, Nigeria. The pulp of the fruit was extracted by removing the thick bark of the fruit and scrapping the pulp off using a spatula. The pulp was blended into the fine powder using a blender and stored in an air tight container for analysis. 


\subsection{Proximate Analysis}

Ten gram $(10 \mathrm{~g})$ of the powder was soaked in $100 \mathrm{ml}$ of pre-boiled distilled water. The solution was shaken vigorously and allowed to stand for 24 hours. It was then filtered using Whatman's No. 1 filter paper and concentrated by freeze-drying to solvent free extract. The proximate analysis of the fruit extract for moisture, ash, crude lipid, crude fiber, crude protein and available carbohydrate contents were determined as described by AOAC standard assay method (AOAC, 2005).

\subsection{Phytochemical screening}

Phytochemical tests were carried out by using the standard methods as reported by Harborne (1973), Sofowora (1993), Trease and Evans (1989), Rasal (2005) and Savithramma et al., (2011).

\subsection{Results and Discussion}

\subsection{Results}

Table 1: proximate composition of different species of Detarium Microcarpum

\begin{tabular}{lll}
\hline Parameters & Sample A (\%) & Sample B (\%) \\
\hline Moisture content & $13.86+0.002$ & $14.23+0.082$ \\
Ash content & $3.73+0.030$ & $2.27+0.036$ \\
Lipid content & $9.40+0.059$ & $4.72+0.372$ \\
Crude protein & $21.20+0.361$ & $17.88+0.102$ \\
Crud fiber & $4.32+0.038$ & $4.46+0.062$ \\
Carbohydrate & $47.50+1.060$ & $56.45+0.338$ \\
\hline
\end{tabular}

Table 2: Quantitative Phytochemical Analysis of Detarium microcarpum Species

\begin{tabular}{lclll}
\hline Sample & Tannin $\%$ & Alkaloids $\%$ & Saponin $\%$ & Flavonoid $\%$ \\
\hline Sample A & $3.16 \%$ & $7.21 \%$ & $10.73 \%$ & $8.56 \%$ \\
Sample B & $3.52 \%$ & $7.41 \%$ & $11.46 \%$ & $7.62 \%$ \\
\hline
\end{tabular}

\subsection{Discussion}

Proximate analysis is used to assess the nutritional quality of samples, among the two samples of Detarium merocarpum, sample A has the highest content of lipid and protein, which are important nutrients for growth and development needed by young children. Lipid content in sample A is remarkable, it could be a good source of edible vegetable oil if well utilized, and could supplement conventional sources. Lipids supply the body with more energy; approximately twice that of carbohydrate and protein and eases intestinal absorption and transfer (Dreon et al., 1990).

However, Sample B contains higher moisture content and carbohydrate compared to sample A. Moisture content affects the physical and chemical properties of food and is accountable for their vulnerability to microbial attack during storage (Hassan et al., 2008). The higher moisture content might be due to storage methods used after harvest of the sample. The moisture content in both samples is close to that reported by Kini et al (2010). The Ash content which is an indication of mineral content according to Aberoumand and Deokule (2009) was found to be higher in sample A compared to sample B, thus sample A may be used in supplementing mineral deficiency especially in growing children. No remarkable difference was observed in crude fiber contents between the species. Fiber in the diet lessens serum cholesterol level (Abolaji, 2007). And if in very high amount assimilates essential trace elements in the gut. Fiber aids bowel regularity, assists maintain blood sugar levels, decreases constipation, and also averts heart diseases (Wasagu et al., 2013).

Quantitative phytochemical analysis shows no remarkable difference between the species. Phytochemical have been reported to have medicinal uses, phytochemical components such as Flavonoids, tannins, alkaloids and terpenoids are responsible for various pharmacological activities of the plants (Kakudidi, 2004). These phytochemical compounds are synthesized by primary or secondary metabolism of living organisms. Secondary metabolites are taxonomically and chemically diverse compounds with huge function which are extensively used in agriculture, human therapy, veterinary and related scientific research (Kakudidi, 2004).

\subsection{Conclusion}

The findings of this study showed that Detarium merocarpum fruit pulp is rich in various phytochemicals and nutritional parameters which may be responsible for the reported pharmacological activities of the plant.

\section{Reference:}

Abdalbasit, A.M., Mohamed E.S., Mirghani, A.B.A and Siddig, I.A. (2009). Detarium microcarpum Guill and Perr fruit proximate chemical analysis and sensory characteristics of concentrated juice and jam. African 
Aberoumand, A. and Deokule, S.S. (2009). Proximate and mineral composition of wild coco (Eulophia ochreataL.) tubers in Iran. Asian Journal of Food and Agro-Industry, 2 (02): 203-209.

Abolaji, O.A., Adebayo, A.H. and Odesanmi, O.S. (2007). Nutritional qualities of three medicinal plant parts (Xylopia aethiopica, Blighia sapida and Parinari polyandra) commonly used by pregnant women in the western part of Nigeria. Pakistan Journal of Nutrition, 6(6): 665-668.

Abreu, P. and Relva, A. (2002). Carbohydrates from Detarium microcarpum bark extract. Carbohydrates Research, 337, 1663-1666. https ://doi.org/10.1016/s0008 -6215(02)00025 -3.

Anhwange, B. A., Ajibola, V. O. and Oniye, S. J. (2004). Chemical studies of the seeds of Moringa oleifera (Lam) and Detarium microcarpum (Guill and Perr). Journal of Biological Sciences. 4(6): 711-715.

AOAC. (2005). Official Methods of Analysis International, 18th edition, Association of Official Analytical Chemists, Washington DC.USA pp. 6-8.

Barminas, J. T., Maitera, O. N. and Solomon, N. (2012). Phytochemical screening and antimicrobial activity of Detarium microcarpum root extracts obtained in Demsa, Adamawa state Nigeria. Journal of Current Engineering Research. 2(4): 6-14.

Dreon, D.M., Vranizan, K.M., Krauss, R.M., Austin, M.A., and Wood, P.D. (1990). The Effects of polyunsaturated fat and monounsaturated fat on plasma, lipoproteins. Journal of American Medical Association, 263: 2462.

Hassan, L.G., Muhammad, M.U., Umar, K.J. and Sokoto, A.M. (2008). Comparative study on the proximate and mineral contents of the seed and pulp of sugar apple (Annona squamosa). Nigerian Journal of Basic and Applied Sciences. 16(2): 179-182.

Kakudidi, E. K. (2004). Cultural and social uses of plants from and around Kibale National Park, Western Uganda. African Journal of Ecology. 42: 114-118.

Kini, F., Ouédraogo, S. and Guissou, P. I. (2010). Propriétés Nutritionnelles et thérapeutiques du fruit de Detarium microcarpum Guill. \& Perr. Fruit. Vegetables and Cereal Science and Biotechnology. 4: 26-30.

Kouyaté A.M. and Lamien, N. (2012). Detarium microcarpum, sweet detar. Conservation and Sustainable Use of Genetic Resources of Priority Food Tree Species in sub-Saharan Africa. Bioversity International 4: 1-8.

Kouyaté, A. M., \& Lamien, N. (2011). Detarium microcarpum, sweet detar. Conservation and sustainable use of genetic resources of priority food tree species in Sub-Saharan Africa. Rome: Bioversity International.

Obun, C. O., Yahaya, M. S. and Kibon, A. (2011). Ukim C (2011). Effect of dietary inclusion of raw Detarium microcarpum seed meal on the performance and carcass and organ weights of broiler chicks. American Journal of Food and Nutrition. 1(3): 128-135.

Olugbuyiro, J. A. O., Moody, J. O. and Hamann, M. T. (2009). Inhibitory activity of Detarium microcarpum extract against hepatitis C virus. African Journal of Biomedical Research. 12(2): 149-151.

Taita, P. (2003). Use of woody plants by locals in Mare aux Hippopotames Biosphere Reserve in western Burkina Faso. Biodiversity and Conservation 12: 1205-121.

Vautier, H., Sanon, M., and Sacandé, M. (2007). Detarium microcarpum Guill. \& Perr. Forest \& Landscape Denmark, Millennium Seed Bank Project. Seed Leaflet. 122 p.

Wasagu, R. S. U., Lawal, M., Shehu, S. Alfa, H. H., \& Muhammad, C. (2013). Nutritive values, mineral and antioxidant properties of Pistia stratiotes (water lettuce). Nigerian Journal of Basic and Applied Science. 21(4): 253-257. 